\title{
Bibliometric Analysis and Visualization of Political Patronage Articles in Indonesia Indexed in Scopus
}

\author{
Yeyen Subandi ${ }^{1}$, Achmad Nurmandi ${ }^{2}$, Zuly Qodir ${ }^{3}$, Hasse Jubba ${ }^{4}$, Titin Purwaningsih ${ }^{5}$, \\ Tri Hastuti Nur Rochimah ${ }^{6}$, M. Syamsurrijal ${ }^{7}$ \\ \{yeyensubandi@gmail.com ${ }^{1}$ \}
}

Program of Islamic Politics-Political Science at Universitas Muhammadiyah Yogyakarta and Lecturer of Department International Relations at Universitas Respati Yogyakarta, Indonesia ${ }^{1}$, Lecturer of Doctoral Program of Islamic Politics-Political Science Universitas Muhammadiyah Yogyakarta, Indonesia ${ }^{2,3,4}$, Lecturer of Department of Government Science at Universitas Muhammadiyah Yogyakarta, Indonesia ${ }^{5}$, Lecturer of Department of Communication Science at Universitas Muhammadiyah Yogyakarta, Indonesia ${ }^{6}$, Student of Doctoral Program of Islamic Politics-Political Science at Universitas Muhammadiyah Yogyakarta, Indonesia?

\begin{abstract}
This research aims to analyze the bibliometric characteristics and trends of articles on political patronage on Indonesia indexed by Scopus. For data retrieval taken from the Scopus database. Retrieval of data on articles that were traced in July 2021 with existing restrictions in Indonesia. The keywords used in this study are political patronage and Indonesia. This study using simple statistical methods and bibliometric analysis with VOSviewer software. This study visualizes the co-occurrence pattern of keywords, document citations, cocitation relationships, and bibliographic merging. The research on political patronage that have taken place in Indonesia has been minimal in the last five years. The results obtained from articles on political patronage have been published in more than 53 journals. Bibliometric analysis shows nine documents have the most significant citation relationship, 53 journals have the largest coupling network, and 72 documents have the most significant bibliographic coupling relationship. Research in the field of political patronage in Indonesia has experienced a decline from last five years.
\end{abstract}

Keywords: Bibliometric analysis; Patronage; Political Patronage; Indonesia; Scopus Database; VOSviewer

\section{Introduction}

Patronage is a two-way relationship between patron and client. Patrons are individuals or groups with material and non-material resources above the client, while actors with control for specific interests own resources. Resources can also be interpreted as something that can be controlled by actors (Ritzer, 2011). Political patronage can be interpreted as a two-way relationship between patron and client in the scope or dynamics of politics. In the Indonesian 
political system regarding patronage relations, there are still not many studies that discuss this topic (Ufen, 2012). Regarding the practice of patronage or political patronage, many things are going on in Indonesia, but not much research has been done yet.

Patronage or political patronage still occurs in Indonesian politics as a developing country. In the regional head election or gubernatorial election in the Special Capital Region of Jakarta in 2017, Anies Baswedan and Sandiaga Uno as governor candidates carried out the practice of political patronage by cooperating with community organizations in gaining winning votes, namely the Betawi Children's Communication Forum community organization (FORKABI) (Dina, 2018). Regarding patronage or political patronage relations, according to Roniger (2004), Titeca (2006), Mair (2006), Kopecky et al. (2011), and Ramli (2016), even though in the current era of development and democracy, both in emerging countries, developing countries, and developed countries.

Regarding patronage or political patronage that occurs in Indonesia, the authors who wrote and published article documents on Scopus in their database from 1994 to 2021 are as follows:

Table 1. Scopus article document

\begin{tabular}{ccc}
\hline Number & Year & Number of documents article \\
\hline 1 & 1994 & 1 \\
2 & 1997 & 2 \\
3 & 2002 & 1 \\
4 & 2003 & 1 \\
5 & 2004 & 1 \\
6 & 2005 & 1 \\
7 & 2006 & 1 \\
8 & 2007 & 1 \\
9 & 2011 & 2 \\
10 & 2012 & 6 \\
11 & 2013 & 8 \\
12 & 2014 & 5 \\
13 & 2015 & 7 \\
14 & 2016 & 5 \\
15 & 2017 & 5 \\
16 & 2018 & 8 \\
17 & 2019 & 4 \\
18 & 2020 & 8 \\
19 & 2021 & 5 \\
\hline & Source: Data from Scopus
\end{tabular}

From the table above, that author's interest in writing articles about political patronage or patronage in Indonesia is very little. Therefore the author is currently strengthened by the previous opinion, namely Oven, 2012 that in the Indonesian political system, there is still not much research on patronage or patronage. Political. There was no significant increase in articles from the Scopus database of research on patronage or political patronage in the last five years. The current study analyzed the bibliometric characteristics and trends of Indonesia's patronage articles or political patronage from link Scopus database. These findings can provide valuable data for understanding trends in research and discovering the novelty of their research in the area of patronage or political patronage. 


\section{Literature Review}

The bibliometric method is an instrument that is applied to evaluate the progress of a discipline concerning conceptual structures, social, and intellectual (Zupic and $\mathrm{C}^{ }$ater, 2015). Several authors have used bibliometrics to analyze article writing for their journals (RamosRodrígue and Ruíz-Navarro, 2004) such as scientific communication (Borgman and Furner, 2002), journal impact measurement (Glänzel and Moed, 2002), university rankings (Moed et al. al, 1985; Van Raan, 2005) and several other topics. Bibliometric analysis for methods have also been used in various fields of research such as innovation (Biemans et al., 2007), tourism (Merig'Hai et al., 2019; Mulet-Forteza et al., 2018; Vishwakarma and Mukherjee, 2019), business research ( Valenzuela-Fernandez et al., 2019) and geophysics (Mulet-Forteza et al., 2020). So far there is'n research on bibliometrics for politics patronage or patronage in Indonesia.

\section{Methods}

Bibliometric indicators are applied to evaluating bibliographic data, including the number of authors and articles, citations, institutions, and countries. Moreover, the documents used for the analysis were obtained from the largest database of multidisciplinary peer reviews of the Scopus literature (Mongeon and Paul-Hus, 2016). This database is widespread and often used to obtain quantitative analysis (Dur'an-S'anchez et al., 2019). This research is a descriptive bibliometric study based on a literature database. Bibliometric analysis was conducted to observe the distribution of articles of patronage or political patronage in Indonesia.

The data was taken from link Scopus in July 2021. For research in this study used the Scopus all-year document search option. The results are filtered by determining the patronage analysis or political patronage in Indonesia. Firstly step is to determine the keywords to use. This study uses separate keywords such as "Political and Indonesian Patronage." The second step is to find articles from the Scopus data link. The search was limited to conferences and journal articles on political or Indonesian patronage. Thirdly step is to refine the initial results by excluding duplicate documents and identifying the relevant data or documents. The last step, the data analysis process is carried out using VOSviewer software to analyze the articles or papers.

\section{Results}

All of data taken from Scopus database, for first finding is trending in papers on political patronage in Indonesia published by Scopus. Papers first appeared on Scopus in 1994 (one article). However, in the last five years, the number of published articles has gone up down, there is no significant increase each year. Therefore, 2018 ( 8 article documents) and 2020 (8 article documents) became a turning point for the interest of article writers on political patronage or patronage in Indonesia to publish in Scopus indexed journals spread into 53 journals. 
Table 2. Scopus indexed journal names.

\begin{tabular}{|c|c|}
\hline Number & Journal Name \\
\hline 1 & Environmental Science and Policy \\
\hline 2 & IOP Conference Series: Earth and Environmental Science \\
\hline 3 & Electoral Studies \\
\hline 4 & Religion, State and Society \\
\hline 5 & Southeast Asian Studie \\
\hline 6 & Electoral Studies \\
\hline 7 & E3S Web of Conferences \\
\hline 8 & Conflict, Security, and Development \\
\hline 9 & Democratization \\
\hline 10 & Japanese Journal of Southeast Asian Studies \\
\hline 11 & Journal of Peace Research \\
\hline 12 & Asian Studies Review \\
\hline 13 & Singapore Journal of Tropical Geography \\
\hline 14 & Third World Quarterly \\
\hline 15 & Contemporary Southeast Asia \\
\hline 16 & Journal of Southeast Asian Economies \\
\hline 17 & Comparative Political Studies \\
\hline 18 & International Journal of Educational Development \\
\hline 19 & Journal of Contemporary Asia \\
\hline 20 & International Political Science Review \\
\hline 21 & WIT Transactions on the Built Environment \\
\hline 22 & Contemporary Southeast Asia \\
\hline 23 & Studies in Comparative International Development \\
\hline 24 & Journal of Sustainable Finance and Investment \\
\hline 25 & Forest Policy and Economics \\
\hline 26 & Asian Social Science \\
\hline 27 & International Journal of the History of Sport \\
\hline 28 & Asian Politics and Policy \\
\hline 29 & Asian Survey \\
\hline 30 & Journal of Asian Studies \\
\hline 31 & Journal of Current Southeast Asian Affairs \\
\hline 32 & The Haze Problem in Southeast Asia: Palm Oil and Patronage \\
\hline 33 & Critical Asian Studies \\
\hline 34 & Pacific Review \\
\hline 35 & Asian Journal of Political Science \\
\hline 36 & International Environmental Agreements: Politics, Law and Economics \\
\hline 37 & Money, Power, and Ideology Political Parties in Post-Authoritarian Indonesia \\
\hline 38 & Al-Jami'ah \\
\hline 39 & Pacific Affairs \\
\hline 40 & Wetlands \\
\hline 41 & Southeast Asia Research \\
\hline 42 & Asian Journal of Social Science \\
\hline 43 & Korean Journal of Defense Analysis \\
\hline 44 & European Journal of East Asian Studies \\
\hline 45 & Public Administration and Development \\
\hline 46 & Routledge Handbook of Southeast Asian Politics \\
\hline 47 & Divine Inspirations: Music and Islam in Indonesia \\
\hline 48 & Journal of East Asian Studies \\
\hline 49 & Southeast Asia Research \\
\hline 50 & International Social Science Journal \\
\hline
\end{tabular}




\begin{tabular}{cl}
\hline Number & \multicolumn{1}{c}{ Journal Name } \\
\hline 51 & The Governance of East Asian Corporations: Post Asian Financial Crisis \\
52 & Thesis Eleven 69 \\
53 & AIDS weekly plus
\end{tabular}

Source: Scopus Database

Next step is to visualize data on existing patronage or political patronage papers in Indonesia in terms of countries related to co-authoring, author keywords related to cooccurrence, publication sources related to citations, and bibliographic aggregation.

For first visualization is co-authorship related to the state. The co-authoring analysis of countries aims to determine the communication and influence between countries in writing articles on patronage or political patronage. The distribution map of the co-author's country network is shown in Figure 1:

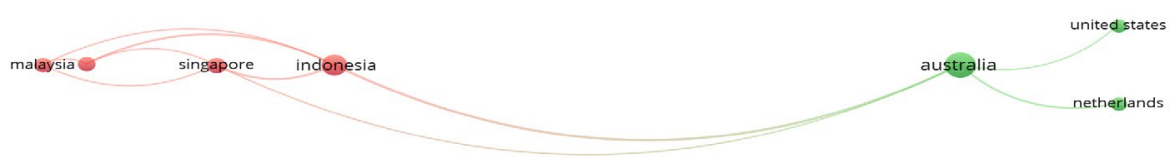

Figure 1. Co-authoring network of articles on political patronage or patronage in terms of countries.

Figure 1 above shows that Indonesia's co-writing of patronage articles or political patronage has affiliations with 15 countries. The color of the nodes represents the diversification of research fields that form 2 clusters. In figure 1, the large vertices show significant states. Links between nodes indicate the relationship between countries, and the link thickness and distance between nodes indicate the degree of collaboration between countries. As shown in Figure 1, the center of the network is Indonesia because articles are written about patronage or political patronage in the Indonesian state. The major countries for writing collaboration are Malaysia, Singapore, Australia, Australia, the United States, and the Netherlands.

While the visualization of co-authorship related to the authors found a maximum of 25 documents for each author, and a minimum of 4 documents, for 86 authors. Below is a picture of the co-authoring network of articles on political patronage in terms of authors:

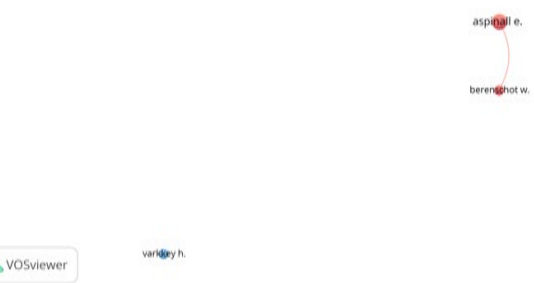

Figure 2. Co-authoring link of articles on patronage or political patronage in terms of authors. 
From Figure 2 above, the results of the bibliometric analysis found three groups: First group or cluster, namely Aspinall e. and Berenschot w., then the second cluster is Fukuoka y., and the third cluster is Varkkey $h$.

The distribution map of keywords in patronage papers or political patronage is presented in Figure 3. When 406 keywords were filtered using at least four keyword appearances, 14 keywords met the threshold. The size of nodes and words in Figure 3 represents the weight of each keyword, with a larger size indicating a greater weight. The keyword "Indonesia" is the most common one that appears 49 times, followed by "patronage" 13 times, "clientelism" 14 times, and "democracy" 9 times, as shown in Figure 3:

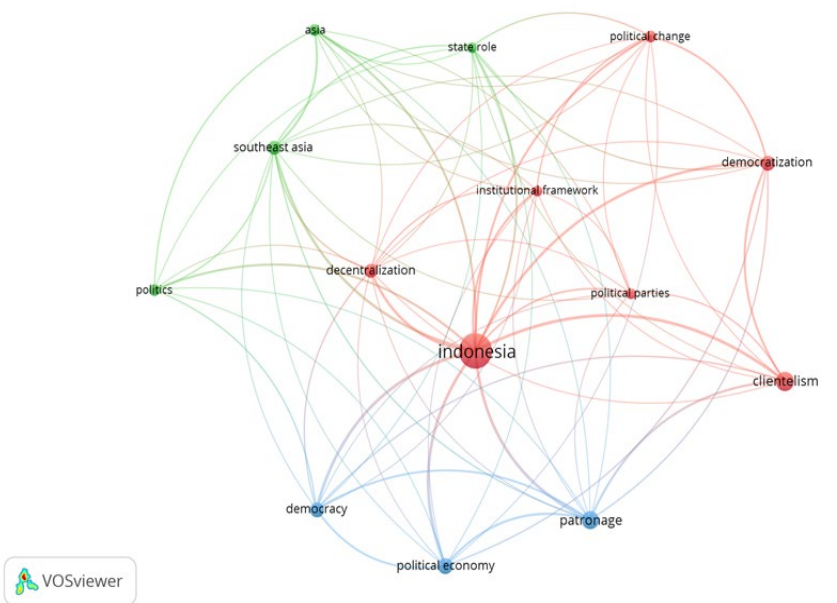

Figure 3. Network of co-occurrence of keywords in articles about patronage or political patronage.

Furthermore figure 3 above, the distance between nodes reflects the strength of the relationship between these nodes. A shorter range indicates a stronger connection. Links between two keywords indicate that they occur together, while link thickness indicates the density of co-occurrence. Nodes with the same color belong to a cluster. As shown in Figure 3 , the "Indonesia" node has thick lines connecting it with clientelism, democratization, decentralization, institutional framework, and political change.

Meanwhile, the visualization of citations from articles about patronage or political patronage with condition publication data sources based on VOSviewer has 72 document sources. However, when the filter is applied to sources with at least one document and two citations, 58 document sources meet the threshold, and VOSviewer divides them into 6 clusters. Of the 58 sources that met the threshold, only 20 documents had strong connections between each other, in Figure 4: 


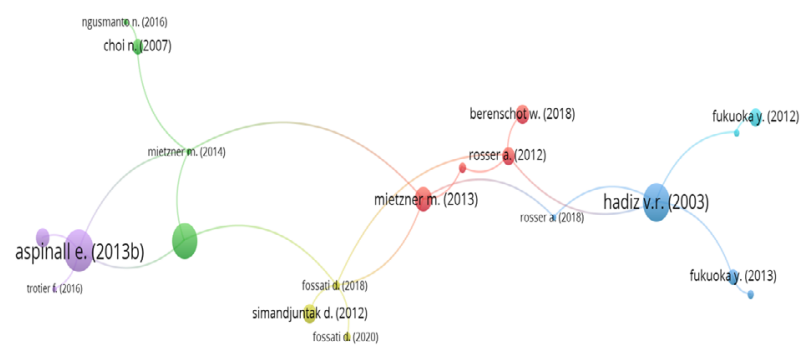

Figure 4. Network of citations of articles on patronage or political patronage in terms of the source of publication documents.

The color of the nodes from figure 4 corresponds to the separate clusters defined. The size of the node indicates the number of citations received by the source. The thickness of the link and the distance of the nodes indicate the closeness and strength of the relationship between the nodes. Thicker nodes and closer distances indicate more frequent and stronger relationships. As shown in figure 4. Meanwhile, the journal most frequently cited by the author in the Journal of Critical Asian Studies with 171 citations, then in second place followed by the Journal of Contemporary Asia with 88 citations, and in third place followed by the Journal of Democratization with 31 citations, and Journal of Contemporary Southeast Asia with 24 citations, in Figure 5 below:

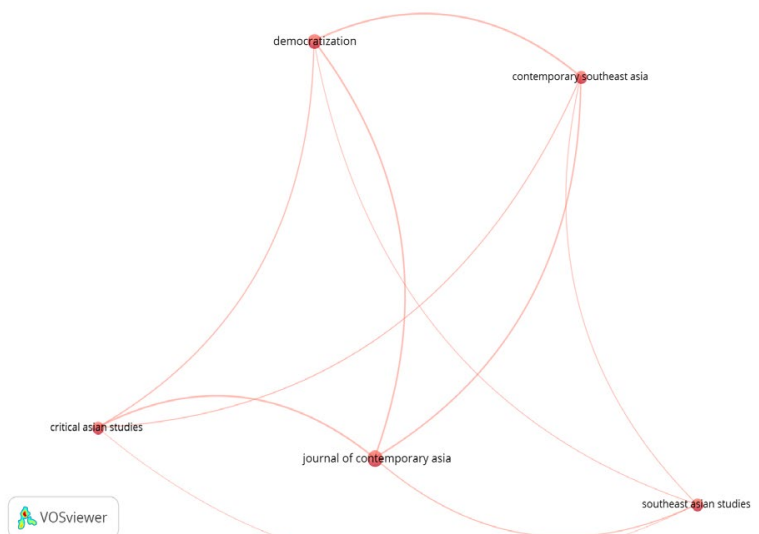

Figure 5. Coupling-source bibliographic link on patronage or political patronage in terms of document citation sources.

VOSviewer in the bibliographic coupling articles found 72 documents with at least one document and found 58 thresholds. The first most cited was Aspinall e (2013b), with 90 citations. Then the second rank was followed by Hadiz v.r (2003) with 72 citations, and then the third rank was followed by Indonesian writer Purnomo (2017) with 69 citations. 


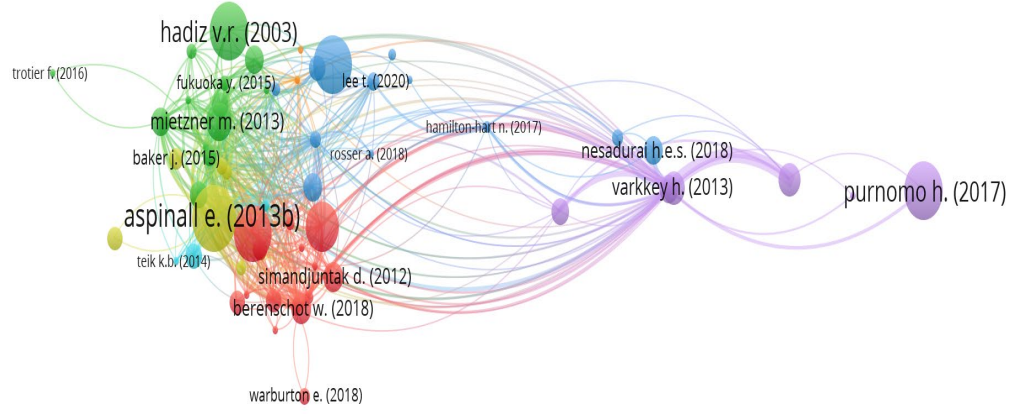

Figure 6. Bibliographic network-coupling of articles on patronage or political patronage.

As shown in Figure 6 above. The distance between the two nodes represents the closeness of the relationship between the two researchers. In other words, authors who are close to each other tend to cite the same article.

\section{Discussion}

The above results show detailed bibliographic characteristics of articles in 53 Scopus indexed journals. Research on political patronage or patronage in recent years has not shown a significant increase. Sometimes there is a decline. This shows that international research publications on political patronage or patronage have not been significantly developed and have not received much interest. Although based on the journal in which the article was published, it appears that the scientific community worldwide has widely accepted research on political patronage or patronage. It can be seen in the database of 53 journals indexed by Scopus.

VOSviewer analysis shows the authors have relationships with researchers from more than 15 countries. This means that Indonesian writers are also active in collaborating with researchers from other countries, such as Malaysia, Singapore, Australia, Australia, the United States, and the Netherlands. In co-occurrence analysis regarding keywords shows the patterns and relationships between keywords that appear together in an article. These keyword patterns make it easier for researchers to identify patterns in the new research. As mentioned earlier, the focus of recent research is patronage relations or political patronage in Indonesia. Because of that, as shown in Figure 3, there is a broad scope for research on how patronage relations or political patronage is associated with Indonesia. In line with that, clientelism, democratization systems, decentralization, institutional frameworks, and political change also have a broad scope for future research or further research.

For figures 2 and 4 show no direct correlation between the number of publications in a particular journal and the number of citations. Furthermore in addition, bibliographies related to coupling documents show the proximity and influence patterns of articles. Of the 72 documents, there are 25 full documents and four minimum documents with 86 authors. 


\section{Conclusion}

All articles in patronage relations or patronage in Indonesia published in Scopus indexed journals is still stagnant, especially for last five years. There is not significant enhancement. The study results show that the authors have very open opportunities to collaborate with researchers from other countries. The practice of patronage relations or political patronage in Indonesia is still not widely studied even though patronage or political patronage is still a lot and continues to occur in Indonesia and other parts of the world. The results of the study the research in patronage or political patronage in Indonesia are widely available and accessible for future research.

\section{Acknowledgments}

Authors thank to journals of Scopus and the bibliometric analysis tool VOSviewer.

\section{Reference}

[1] Biemans, W., Griffin, A. and Moenaert, R. 2007. "Twenty years of product innovation management journals: history, participants, and the supply and flow of knowledge." Journal of Product Innovation Management. Vol. 24 No. 3, p. 193-213.

[2] Borgman, CL and Furner, J. 2002, "Scientific and bibliometric communication." Annual Review of Information Science and Technology. Vol. 36 No. 1.

[3] Dina Fadiyah dan Ummi Zakiyah. 2018. "Menguatnya Ikatan Patronase dalam Perpolitikan Indonesia". MADANI Jurnal Politik dan Sosial Kemasyarakatan. Vol. 10, No. 2 (2018): e-ISSN 2620-8857: p-ISSN 2085-143X. Universitas 17 Agustus 1945 Jakarta.

[4] Dur'an-S'anchez, A., Del Río-Rama, M., de la, C., lvarez-García, J. García-Vélez, DF. 2019. "Mapping Haif scientific coverage of education for entrepreneurship in higher education." Journal of Enterprising Communities: People and Places in the Global Economy, Vol. 13 Nos 1/2, JEC-10-2018-0072.

[5] George Ritzer dan Doughlas J. Gooman. 2011. Teori Sosiologi dari Teori Sosiologi Klasik Sampai Perkembangan Mutakhir Teori Sosial Postmodern, Yogyakarta, Kreasi Wacana.

[6] Genzel, W. and Moed, HF. 2002. "Measurement of the impact of journals in bibliometric research." Scientometrics. Vol. 53 No. 2, p. 171-193.

[7] Kristof Titeca. 2006. "Political Patronage and Political Values: The Developmental Role of political Patronage and Its Impact on Shaping Political Values and Rural Uganda". Afrika Focus, Vol. 19, Nr. 1-2, pp. 43-67. Vakgroep.Studie Van de Derde Wereld Universiteit Gent, Universiteit 8,9000 gent, Belgium. kristof.titeca@ugent.be

[8] Luis Roniger. 2004. "Review Article: Political Clientelism, Democracy, and Market Economy." Comparative Politics. Vol. 36, No. 3 (Apr), pp. 353-375. Published by: Ph.D. Program in Political Science of the City University of New York. Downloaded from http://www.jstor.org/stable/4150135.

[9] Merig'Hi, JM, Mulet-Forteza, C., Valencia, C. and Lew, AA. 2019. "Twenty years of tourism geography: a bibliometric overview." Tourism Geography. Vol. 21 No. 5, pp.881-910. 
[10] Moed, HF, Burger, WJM, Frankfort, JG and Van Raan, AFJ. 1985. "Use of bibliometric data for measurement of university research performance." Research Policy. Vol. 14 No. 3, pp. 131-149.

[11] Mongeon, P. and Paul-Hus, A. 2016. "Science web journal coverage and Scopus: Comparative analysis." Scientometrics. Vol. 106 No. 1, p. 213-228.

[12] Muhammad Ramli. 2016. "Patronase Politik dalam Demokrasi Lokal-Analisis Terhadap Terpilihnya Hj. Marniwati Pada Pemilukades di Desa Jojjolo Kecamatan Bulukumpa Kabupaten Bulukumba”. Fakultas Ushuluddin Filsafat dan Politik-Jurusan Ilmu Politik: UIN Alauddin Makassar.

[13] Mulet-Forteza, C., Martorell-Cunill, O., Merig'o, JM, Genovart-Balaguer, J. and Mauleon-Mendez, E. 2018. "Twenty-five years of travel and tourism marketing journals: a bibliometric ranking." Journal of Travel and Tourism Marketing. Vol. 35 No. 9, p. 1201-1221.

[14] Mulet Forteza, C., Socias Salv, Monserrat, S. and Amores. 2020. "The 80th anniversary of pure and applied geophysics: a bibliometric overview". Pure and Applied Geophysics. Vol. 177 No. 2, pp. 531-570.

[15] Petr Kopecky and Peter Mair. 2006. "Political Parties and Patronage in Contemporary Democracies: An in Introduction." European University Institute and Leiden University. Paper prepared for the workshop on Political Parties and Patronage, ECPR Joint Sessions of Workshops, Nicosia, 25-30 April.

[16] Petr Kopecky., Maria Spirova, and Gerardo Scherlis. 2011. "Beyond the Cartel Party? Party Patronage and the Nature of Parties in New Democracies". Paper prepared for the joint IPSA/ ECPR conference, Sao Paulo, Brazil, 16-19 February.

[17] Ramos-Rodrígue, AR and Ruíz-Navarro, J. 2004. "Changes in the intellectual structure of strategic management research: a bibliometric study of strategic management journals, 1980-2000". Journal of Strategic Management. Vol. 25 No. 10, p. 981-1004.

[18] Valenzuela-Fernandez, L., Merig'Hai, JM, Lichtenthal, JD, and Nicolas, C. 2019. "A first 25-year bibliometric analysis of a business-to-business marketing journal". Journal of Business-to-Business Marketing. Vol. 26 No. 1, pp. 75-94.

[19] Vishwakarma, P. and Mukherjee, S. 2019. "Forty-three years of tourism leisure research travel: a bibliometric analysis." Tourism Recreation Research. Vol. 44 No. 4, pp. 403-418.

[20] Zurich and C`ater, T. 2015. "Bibliometric methods in management and organization." Organizational Research Methods. Vol. 18 No. 3, pp. 429-472. 